\title{
DETERMINING MOODLE SELF-EFFICACY BASED ON LANGUAGE ONLINE LEARNING ENVIRONMENT IN HIGHER EDUCATION
}

\author{
Rizky Eka Prasetya \\ Akademi Sekretari Budi Luhur \\ rizky.ekaprasetya@budiluhur.ac.id
}

\begin{abstract}
The Learning Management System (LMS) self-efficacy determined the learner established their capabilities and confidence through virtual learning activities' positive mindset. The integration of experiences and abilities was developed to impact Moodle as the electronic learning facilities efficiently. The purpose of the study was to aim the investigations and determination to the LMS Moodle Self-efficacy in language learning pedagogy. The study's design was conducted mixed research method collaborated to the quantitative and qualitative approach, and sequential basic structuralized applied to the sequential phase (quantitative and qualitative). The objective of the study took on the 257 language learners in Higher Education. The application scale of LMS Moodle selfefficacy integrated into language learning in Higher Education and involved the 22 questionnaires in selecting dichotomy to agree and disagree point of the Likert scale. The study's result had exposed the three-scales enhance to the platform of Moodle self-efficacy of accessing, Moodle self-efficacy of communication, and Moodle self-efficacy of electronic testing and feedback. The exploratory LMS Moodle self-efficacy had a maximum point range of around 0.73 and 0.92 , and the condition had established to the participants' respondents and variation in each statement. Consequently, these three scales demonstrated unbiased responses toward the questionnaire items, and the online language learners conduced to comprehend Moodle become the adaptive LMS to completely implement the English language learning strategy. Nevertheless, the communication and versatility access needed to develop well in conducting language learning content so learners would feel encouraged and motivated following virtual language learning.
\end{abstract}

Keyword: Self-Efficacy; Language Learning; LMS Moodle; Online Learning

\section{INTRODUCTION}

Higher Education students maintained their learning open online education and conference video with their lecturers, especially in Jakarta's prominent cities. Nadeak (2020) asserted that the alternative condition suited a crucial solution to overcome the restriction activities anticipating the worldwide coronavirus spread in Indonesia. Learners were not engaging in the studying from the home program because of the online course confused to arrange to as many Indonesian pedagogical members had not denoted to prepare through electronic class or practices previously. Churiyah et al. (2020) added that the digital condition remained challenging and an obstacle to implementing perfectly in the electronic pedagogy ecosystem. The online learners admitted that the electronic course activities workload was more demanding than in conventional classes for higher education goals or outcomes. Besides, lack of communication greatly impacted the Learning Management system's learning adaptability as common online practices (Hasani et al.,2020).

The appearance of innovative technologies might manage to more effective teaching and learning in English pedagogy. Nawaila et al. (2020) clarified that lecturers and learners of foreign languages are also knowledgeable of the prevailing technologies. Consequently, all the participants should intensify their Computer-Assisted Language Learning (CALL) knowledgeability. Language learners were extremely fascinated in employing CALL, yet English lecturers composed tremendous struggles to accommodate CALL toward their teaching style and approach (Troussas et al., 2019). Cautious prompt pedagogy participants understand the necessity of developing their CALL education. Notwithstanding, it should be viewed that CALL procedures could be modified or established by personal distinctions. CALL is progressing, learning willingly than regulation. The condition is considering a learners-centered plan 
instead of a lecturers-centered one. Schmid (2017) competed that electronic learning's disadvantage started to change a new expression denominated 'blended learning or flipped learning' integrating online and conference communications. There is no uncertainty that Information Communication Technologies (ICT) change how languages are being prepared and studied.

Most investigations have been initiated to examine the circumstances that keep affecting integrating the Moodle principles in many English Foreign Language (EFL) circumstances. Numerous research studies have previously exposed an essential concern in both educators and learners to accommodate Moodle in language pedagogy because they understand that the application improves the language learning progress (Natalia and Julia. 2018; Gundu and Ozcan. 2017; Al Bataineh et al., 2019). The application of Moodle promotes a learner-centered address from both instructors and learners engage in the electronic course. A variety of analyses explicated that Moodle practice contributes to comprehensive learning internal and external in the electronic course. In this recognition, Moodle conveyed influence in the academies as a necessary component of the blended or fully online learning opportunity, which is frequently expressed of direct and online programs to preparation.

Moodle generated safer and proper pedagogical in implementing VLE (virtual learning environment). Kapsargina and Olentsova (2020) established that the term referred to integrating several electronic instruments and activities to enhance the teaching and learning process. The Moodle instrument is separated between Activities tools and Resources tools. Kerimbayev et al. (2020) mentioned the number of learning activities that Moodle recommended, essentially online learning circumstances involving teaching style of electronic learning, distance learning, blended classroom, and mixed learning. Moodle program empowers language learners to receive content every time and every place proper for them in acquiring language learning and brought clarity, great direction, and students' self-analysis. Alhothli (2015) identified three benefits of LMS Moodle endeavored English language learning. The first advantage was bolstered student-centered education, and the second other genuine object was its exclusive feature for learning, notwithstanding distance and circumstances. Furthermore, Moodle obtained the comfort of course management.

Electronic learning's essential characteristics are the presentation of material contributed with interactive media objectives in online learning circumstances, online teaching model (synchronous or asynchronous) as the interaction activities, and independent time and place to language learners. Furthermore, Shurygin and Krasnova (2016) indicated that eLearning situations facilitate several modes of exchanging information mechanization applied on self-learning platforms. Among the most significant constituents in the social cognitive approach, self-efficacy is described by Sun and Hsu (2019) as a condition that influences an entities' perception of themselves and how their response develops, affecting their potential to create the important activities' particular achievement to arrange it favorably. Alqurashi (2016) exposed that self-efficacy essentially an individual's expectations concerning how well learners could implement the efforts needed to cope with possible circumstances. Established on these descriptions, promoting individuals' views may also influence their learning performances. Yavuzalp and Bahcivan (2020) emphasized that self-efficacy requires individuals' experiences of their ability to fulfill and achieve in communicative practice. Self-efficacy is commonly noticed in individuals' accomplishment of agitated duties that they have earlier completed.

It is assumed that self-efficacy scales elaborated for electronic course environments, which progress swiftly under technical developments and investigate new instruments and devices. Accordingly, Baltaoğlu and Güven (2019) affirmed that the latest scales evolved and required to implement more reliable outcomes that adapt to prevailing contingencies. After reviewing the education and scales specified before, it might be agreed that under the reflection of the innovations of Moodle as an online learning medium, number of objects, and contemporary distance learning technologies.

Self-efficacy patterns are customarily given as outlines studies on which object or respondents assess their capacity to complete a provided task effectively and efficiently. The respondents are not required to achieve the assignment. Self-efficacy and computers are principally associated with learners' belief in 
utilizing computers and other characters of technology. The study results of Müller and Seufert (2018) found a positive and meaningful relationship between the computer and earlier background self-efficacy with electronic learning. The Online Learning Self-Efficacy Scale (OLSES) scale was promoted by Zimmerman and Kulikowich (2016) and include 22 objects and three sub-objects (learning in the virtual environment, course management, and technology practice). The most distinctive feature that distinguishes the OLSES scale from another is the evidence that no notable discrepancy was discovered when it was completed with various learner assortments with and without virtual learning practice after the scale's advancement. Consequently, development timely scales might be demanded to implement more specific decisions that correspond to general conditions. the circumstances could be noted in reflecting the instrument of online or virtual learning technologies.

Moreover, the previous scales stated, it is comprehended that existed investigations (De Smul et al.,2018; Kang et al.,2019; Tsai et al.,.2021) directed at discovering learners' self-efficacy attention in online learning environments. The condition included the limitation and restriction scale-environment to the self-efficacy applied in assimilated to the psychological attributes, including limited scale items related to self-efficacy used in conjunction with other psychological factors (encouragement, self-learning, achievement, etcetera). The significant matters came up to the investigations and explorations to the LMS Moodle self-efficacy as the primary instrument to the effective and efficient for language learning Higher Education. The limitation study restricted by the research question involves 1) what are selfefficacy attribute language learning to the LMS Moodle; 2) What strategies can increase LMS Moodle self-efficacy language learning?

\section{METHODOLOGY}

The study implemented the mixed methods study intentionally blending quantitative and qualitative procedures as the research elements. The approach's purposes were to explore the complexity of focus study, particularly self-efficacy based on Moodle as an English language learner's media in Higher Education. The determination of the mixed basic design of explanatory and to represent the investigation problem in intensity. To accomplish this, it first employed a quantitative study to estimate the qualities or characteristics of the Moodle self-efficacy and later a qualitative study to expand the decisions of the study of the purposes.

The respondents or participants came from language learners in Higher Education from Jakarta, consisting of 4 Universities as the representative sample. They established similar experiences for learning English as Foreign Language in full online through LMS Moodle for one year, and they were around 19-21 years old. The detailed information is in table 1 below.

Table 1 Participants General Demographic

\begin{tabular}{lccc}
\hline \multirow{2}{*}{ Items } & Element & $\begin{array}{c}\text { Total of } \\
\text { Participants (N) }\end{array}$ & $\begin{array}{c}\text { Total in } \\
\text { Percentage (\%) }\end{array}$ \\
\hline \multirow{2}{*}{ Gender } & Male & 168 & $65 \%$ \\
\hline LMS Moodle & Female & 89 & $35 \%$ \\
\cline { 2 - 4 } Learning & Poor & 97 & $38 \%$ \\
Experience & Moderate & 105 & $40 \%$ \\
\hline \multirow{2}{*}{ Education Major } & High & 55 & $22 \%$ \\
\cline { 2 - 4 } Background & Science Communication & 73 & $30 \%$ \\
& Economics & 80 & $31 \%$ \\
\cline { 2 - 4 } & Engineering & 45 & $16 \%$ \\
\cline { 2 - 4 } & Information Technology & 59 & $23 \%$ \\
\hline
\end{tabular}

The Moodle self-efficacy survey was distributed to the 257 students of language learning through LMS Moodle. The Martin and Tutty (2008) adaptation Learning Management System Self-Efficacy Survey 
(LMSES) was divided into three Moodle-related categories, and two demographic questions agree to disagree. Several statements were adjusted to the relevance of the research focus. It concentrated on the capabilities and experiences necessitated to handle the learning activities as the Moodle self-efficacy of accessing, Moodle self-efficacy of communication, and Moodle self-efficacy of electronic testing and feedback. The Likert scale involved the dichotomy attribute between agree and disagree selection of each 22 statement element.

Pretesting and piloting identified validity and reliability measures on 59 language learners. The Kaiser Meyer Olkin (KMO) test was applied to the validity questionnaire, and the Cronbach Alpha procedure was implemented to the reliability questionnaire. Two hundred fifty-seven (257) language learners distributed the questionnaire for investigating the significant three-element Moodle self-efficacy scale. The next step is to conduct the 40 respondents to the semi-structured interview to have the feedback and experiences' depth length. The figurative language learners clarifying the survey necessitated part in a structured interview individually. The interview items focused more on the learners' perception point of view as they progressed via LMS Moodle as the online learning medium. The basic structuralized of the study referred to the design of the sequential phase. The preliminaries of research with sequential phases use a research approach to profoundly study the research topics, use the first phase's findings (quantitative phase), and design a quantitative phase in the second phase (qualitative phase)

\section{RESULT AND DISCUSSION}

\section{Validity And Reliability Of The Questionnaire}

The questionnaire was ensured and validated to the 59 language learners before distributed to the 257 total participants. The general result can be observed in table 1. The Kaiser Meyer Olkin (KMO) test was applied to explain the relationship among variables and partial correlation (Wang and Batbileg. 2020). The questionnaire is considered unacceptable if the KMO result is under 0.50 , consequently necessitates extra data gathering and larger samples. The study's measures are acceptable to the investigate Moodle Self-Efficacy Scale, particularly English pedagogy context because the condition established values higher than 0.50 (accessing $=0.871$, communication $=0.728$, and electronic testing and feedback $=0.697$ ). Nevertheless, the Cronbach alpha result showed relatively high reliability (accessing $=0.836$, communication $=0.737$, and electronic testing and feedback=0.892). Its indicators explained good reliability measures around 0.70 to 0.80 (Chen. 2018). The three Moodle Self-efficacy Scale was relatively acceptable to investigate, and the questionnaire was valid and reliable.

Table 2 Reliability and validity Questionnaire

\begin{tabular}{lcc}
\hline \multicolumn{1}{c}{ Moodle Self-efficacy Scale } & KMO & Cronbach alpha $(\alpha)$ \\
\hline Accessing & 0.871 & 0.836 \\
\hline Communication & 0.728 & 0.737 \\
\hline Electronic Testing and Feedback & 0.697 & 0.892 \\
\hline
\end{tabular}

\section{Moodle Self-Efficacy Scale of Accessing}

The total participants of the study referred to the language learners in higher education around the Jakarta area. All of them were established their opinion through an electronic survey google form. As observed in table 1, the mean of self-efficacy accessing English learning via Moodle was found maximum at 128.5 while the minimum at 111. However, Agree and disagree Likert scares had determined the validity of agreeing with s2 (216 points) and disagreeing with s5 (138 points). These indicators of perspectives had clear descriptive that Each item's proportion and range (s1 - s6) revealed the sample population had raised validity and variations. The finding recognized the mean quantity of self-efficacy to language learning online Moodle. 
Table 3 Moodle Self-efficacy Scale of Accessing.

\begin{tabular}{lccccc}
\hline $\begin{array}{l}\text { Accessing the English language } \\
\text { Moodle. (I can) }\end{array}$ & Agree & Disagree & N(\%) & Mean & SD \\
\hline $\begin{array}{l}\text { signing to my English course in the LMS } \\
\text { Moodle (S1) }\end{array}$ & 192 & 60 & $\begin{array}{c}252 \\
(98 \%)\end{array}$ & 128.5 & 93.3 \\
\hline $\begin{array}{l}\text { Understand the text messages or } \\
\text { audiovisual files set by the English } \\
\text { instructor (S2) }\end{array}$ & 216 & 40 & $\begin{array}{c}256 \\
(99 \%)\end{array}$ & 128 & 124.4 \\
\hline $\begin{array}{l}\text { Observe my English instructor's } \\
\text { description, including name: educational } \\
\text { background, office location, and others } \\
\text { (S3) }\end{array}$ & 119 & 121 & $\begin{array}{c}240 \\
(93 \%)\end{array}$ & 120 & 1.41 \\
\hline $\begin{array}{l}\text { Inspect the English learning electronic } \\
\text { course documents online (S4) }\end{array}$ & 131 & 119 & $\begin{array}{c}250 \\
(97 \%)\end{array}$ & 125 & 8.48 \\
\hline $\begin{array}{l}\text { Download the English learning electronic } \\
\text { course documents to my gadget (S5) }\end{array}$ & 109 & 138 & $\begin{array}{c}247 \\
(96 \%)\end{array}$ & 123.5 & 20.5 \\
\hline $\begin{array}{l}\text { Navigate Moodle course materials } \\
\text { efficiently (S6) }\end{array}$ & 97 & 125 & $\begin{array}{c}222 \\
(86 \%)\end{array}$ & 111 & 19.7 \\
\hline
\end{tabular}

The electronic English learning course's primary elements need to be attracted and noticeable, and this implementation can be achieved by offering teaching content in digital mechanisms in the designs of tables, graphs, and other visible intentions. Pikhart (2019) supplemented that the English learning course designer's necessary task is to manage specific learning related to goals and the objectives for certain activities and evaluation guidelines. At this point, presenting detailed information of guidelines and organizing assignment activities should be prepared and manage simultaneously. The electronic pedagogy English language process was developed on the conventional class in the face-to-face meeting, so learners could implement self-learning and understand the system's instructional.

"While I was accessing the electronic material, I expected to have attractive layout content Moodle. I need not open and download the file if I want to observe each material's goal, objective, or instructional lesson. The information should be visible on the first welcoming page so that learners felt simple to access it."

Thus, the structure of the e-course is presented in the following first sections of place general data contained about metainformation related to the English learning course detailed, lecturer's personal information (Nalliveettil and Alenazi. 2016). Second information related to the subject/unit learning, instructional procedure, teaching references, assessment procedure. The last section concluded about testing determination level, feedback guidelines, and etcetera. Suitable usage of exciting motives is advantageous to language learning. It is not only for the electronic learners' ecosystem but also for learners with difficulties accessing the electronic system. The more consistent attraction motivates a language learner to be actively exposed to learning activities, the greater the possibility of learning successfully. There are three principally concerned guiding intention of the visual content on learning Internet sites: learner-centered principles, picture instruments, and picture purposes.

"I think it will be easier for us (language learners) to have simple tools instruction layout design

Moodle. It is important to understand what learners do and do not because it is not always become effective to the virtual learning without confirming to the understanding of the evaluation or assessment."

The knowledge English material quality classifications in tools, approachability, description, and literacy. Each level is correlated with different material characteristic measurements, such as comprehensiveness, distinctiveness, enthusiasm, and innovation. Natalia and Julia (2018) justified that Moodle's link to the internet sites for an education model should describe the utilizing process in it references English learning, and the actual reference source is emphasized. It is significant to confirm 
that the effectiveness of interactive media is an enrichment. Therefore, source instructiveness can be performed by the appearance of recreations and appropriate material. A communication resource between the English lecturers and learners would help deliver and gather views on how the Moodlebased English pedagogy can be improved.

"I did not completely understand the Moodle feature, but our English lecturers inform us in the different platform, Zoom meeting, to have complete information related to the focus tools. We (language learners) had difficulty recognizing each style of other lecturers, even though applying Moodle meeting for more than eight months."

Constructing Moodle systems learning the English language referred to the absolute integrated systems that sustain various English lecturers' and learners' activities throughout the e-learning transformation. Lecturers or instructors apply Moodle to improve web-based electronic course environment and testing, interact with learners, and observe and grade learners' improvement. Yeou (2016) clarified that learners accepted Moodle for learning, exchange interaction, and collaborative enhancement. Moodle participants relate to independent crowds with complex particulars, individual features, and demands. The adjustment of electronic educational methods to a specific group depending on their qualifications believe, experience and choices is the subsequent measure in developing the eLearning ecosystem. The inadequacy of adaptive learning environments or an environment with flexible features is partly due to personalizing concept, which offers the equivalent latent English learning material to all learners.

"it was difficult for me to follow Moodle learning if the lecturers did not give us open communication properly because we knew that chat feature in Moodle was not reliable. Therefore, we need other media to improve our communication problem. It was normally our English lecturer open conversation in smartphone application instant messages. From my perspective, it would be an advantage for me to have a conversation in the video conference."

The emphasis is on learner-centered principles and establishing learners' possibilities, encouragement, attitudes, learning techniques, demands, and etcetera. Shishkina and Malykhina (2015) determined that an e-learning Moodle system is acknowledged to be adjusting and has capabilities to observe its participants' process in the center of engagement. Performing certain predicated on domainparticular patterns would have inferred participants' demands and precedence outward of the explained activities, correctly interpreting these associated forms, and performing simultaneous the possible information on its participants and the material subject control would create dynamically promote the English learning pedagogy. Because the Moodle-system course accommodates a personality, compliance is also designated exemplification.

"Feedback and answer key was the crucial as language learners. It increased the motivation to answer the question because we would know the answer at the end of the session. However, this feature was not applied in the English Moodle course. That was the reason sometimes English lecturer might not be able explained each question."

The Moodle web-based educational system integrates with adjustability and ability by creating individual learners' purposes, choices, and experiences. This system is accommodated to the language learner's requirements by applying the design entirely to the course presentation. Adaptive e-learning Moodle systems concentrate on accommodating the language learning courses to the unique features of the learners. These systems are affirmed to achieve more dependability than others LMS. The ecosystem included quizzes adaptable, adaptive course supervising systems, and adaptive collaboration systems to complete their capacities more productively. Consequently, adaptive systems' fundamental obstacles are considered in the system's construction and accomplishment rather than its core adaptivity. However, Moodle does not implement a sufficient level of adjusting of material and cloud services.

\section{Moodle Self-Efficacy of Communication}


As shown in Table 2, a Self-efficacy value of mean was found maximum score at 128.5 and minimum score 119.5, revealing significantly good sampling adequacy around to the Likert scale agree to reach out 180 (s7) while disagree have on 173 (s12). The standard deviation items that reveal the suitability of data for factor analysis were also significant (S.D less than mean). When the results gathered are assessed, it exposed that the distribution of sample size was enough. Subsequently, necessary element investigation synchronically with the oblivion rotation method was implemented to investigate the scale results' associated efficacy.

Table 4 Moodle Self-efficacy Scale of Communication

\begin{tabular}{|c|c|c|c|c|c|}
\hline $\begin{array}{l}\text { Moodle Asynchronous dan Synchronous } \\
\text { Communication (I can) }\end{array}$ & Agree & Disagree & $\mathbf{N}(\%)$ & Mean & SD \\
\hline $\begin{array}{l}\text { Communicate the English language easily } \\
\text { in chat or discussion forum (s7) }\end{array}$ & 180 & 70 & $250(97 \%)$ & 125 & 77.7 \\
\hline $\begin{array}{l}\text { Interact freely and privately with the whole } \\
\text { less participants (s8) }\end{array}$ & 138 & 111 & $249(96 \%)$ & 124.5 & 19.0 \\
\hline $\begin{array}{l}\text { Notice messages from one or more } \\
\text { participants (s9) }\end{array}$ & 117 & 129 & $246(95 \%)$ & 123 & 8.48 \\
\hline $\begin{array}{l}\text { send text message-based e-mail to my } \\
\text { instructor or other learners (s10) }\end{array}$ & 97 & 148 & $245(95 \%)$ & 122.5 & 36.0 \\
\hline $\begin{array}{l}\text { Conduct text message-based chat to my } \\
\text { instructor or other students (s11) }\end{array}$ & 100 & 139 & $239(92 \%)$ & 119.5 & 27.5 \\
\hline $\begin{array}{l}\text { Set up text message in the discussion } \\
\text { forum }(\mathrm{s} 12)\end{array}$ & 74 & 173 & $247(96 \%)$ & 123.5 & 70.0 \\
\hline $\begin{array}{l}\text { response text message in the discussion } \\
\text { forum }(\mathrm{s} 13)\end{array}$ & 89 & 154 & $243(94 \%)$ & 121.5 & 45.9 \\
\hline $\begin{array}{l}\text { compose text message in the discussion } \\
\text { forum }(\mathrm{s} 14)\end{array}$ & 109 & 148 & $\begin{array}{c}257 \\
(100 \%)\end{array}$ & 128.5 & 27.5 \\
\hline $\begin{array}{l}\text { Observe archived text-based chat feature } \\
\text { (s15) }\end{array}$ & 123 & 134 & $\begin{array}{c}257 \\
(100 \%)\end{array}$ & 128.5 & 7.77 \\
\hline
\end{tabular}

An e-learning Moodle is an arrangement that gives settings essential for managing all perspectives of an English learning electronic class through a singular, instinctive, and compatible network interface. Elearning Moodle-based practices would implement settings that allow learners to change from inactive to engaged learners to participate in the online English language learning process enthusiastically. Iwata et al. (2017) demonstrated that Moodle circumstances provide synchronous and asynchronous communication learning devices. The central challenge for e-learning system English learning designers is implementing a Moodle-based learning method with relevant settings to emphatically influence a participant's participation. The English lecturers as learning designers must invite language learners with suitable electronic content. They should have integrated Moodle ecosystem and mechanization in the electronic learning course acceptably. For these reasons, English lecturers, instructors, and designers of eLearning Moodle-systems must thoroughly recognize the requirements, aims, and benefits of e-learning participants and affirm that the Moodle web-based program will engage their needs.

"I do not know exactly the term synchronous and asynchronous, but I believe communication exchange is important to the process of learning in the electronic environment. Our perspective and lecturers' view had different mind-flow, so we need to collaborate and confirm concerning the difficulties in the system."

Moodle accomplished a device for presenting English electronic content to learners and evaluating learning, practicing electronic testing of assignments or quizzes, and maintaining a thriving collaborative eLearning ecosystem. Syakur (2020) discovered that language learners utilized Moodle to obtain in language courses, interact with other participants, exchange written communication, contribute to topic material invention, communicate amidst English lecturers and other learners completed an incorporated 
messaging order, and upload repositories, review classes, and etcetera. English lecturers or instructors apply Moodle to achieve electronic language learning materials, manage learners and their grades, verify the sent learners' activity, arrange electronic testing, design content utilizing Wikis, etcetera.

"Moodle electronic learning provided us (language learners) to collaborated and exchanged the information related to each subject. However, we need more access to the internet because we could not do anything without it. When you had internet, Moodle was simple to operate."

Recent advances in Moodle technology applied with more reasonable and compelling electronic devices and more webcast, multiplatform applications that complete synchronous and asynchronous written communication tasks. Chang and Lan (2019) emphasized that Moodle encompasses both a constructivist and social constructionist strategy to English pedagogy, learners may provide to the pedagogical practice in many forms. Moodle's characteristics consider the social constructionist procedure in distinctive design features. Moodle advances have elevated capability for supporting the description of the social constructionist viewpoint. While Moodle cannot replace the conventional faceto-face classroom, it remains compelling pedagogy support to electronic classroom communicative features.

"I need to improve my English communicative abilities verbally, but I cannot do that in virtual learning. The condition is not always comfortable for us to learn practically. We do more typingcommunicating, and I think it would have the advantage for me to have English correspondence."

Communication is an indispensable element of eLearning, and Moodle contributes to a wide variety of communication instruments. The conditions have occurred to lecturers and learner's discussion and various interacting tools forums, member Moodle courses, etcetera. Moodle usage for intention communication objectives appears entirely suitable considering the fundamental assumption of electronic learning pedagogy through interaction. Louhab et al. (2017) ascertained that the conception and improvement of Moodle are conducted by social constructionist instruction. Learners actively build innovative information while communicating with others in social contexts in which groups cooperatively design practice of participated moment with shared purposes.

\section{Moodle Self-efficacy of Electronic Testing and Feedback}

The examination from table 3 revealed that the items' circumstance distributions ranged between median maximum reach at 128.5 while minimum exposed for 119.5. The mean factor impact to S.D developed on the 145 agree on item s22, and 150 disagree of item s18. The single structure could collect items of s19, s20, and s22 simultaneously. The participants' self-efficacy counts were reviewed in courses of their online activities. Language learners' mean rank score was slightly more eminent than self-efficacy previously. However, the scale results indicated no integral inequality in students' total self-efficacy scores following their electronic testing and feedback.

Table 5 Moodle Self-efficacy Scale of Electronic Testing and Feedback

\begin{tabular}{lccccc}
\hline $\begin{array}{l}\text { Moodle Electronic Testing and } \\
\text { feedback (I can) }\end{array}$ & Agree & Disagree & N(\%) & Mean & SD \\
\hline $\begin{array}{l}\text { Access quizzes testing style of multiple- } \\
\text { choice, short answer, match, true/false } \\
\text { and others (s16) }\end{array}$ & 138 & 101 & $239(92 \%)$ & 119.5 & 26.1 \\
\hline $\begin{array}{l}\text { Upload the answers' file to the Moodle } \\
\text { (s17) }\end{array}$ & 133 & 119 & $252(98 \%)$ & 126 & 9.89 \\
\hline $\begin{array}{l}\text { Observe the review from quizzes task } \\
\text { (correct or incorrect answer) (s18) }\end{array}$ & 102 & 155 & 257 & 128.5 & 37.4 \\
& & & $(100 \%)$ & & \\
\hline $\begin{array}{l}\text { the review from quizzes task (s19) } \\
\text { (1) }\end{array}$ & 118 & 139 & 257 & 128.5 & 14.8 \\
\hline
\end{tabular}




\begin{tabular}{lccccc}
\hline $\begin{array}{l}\text { See the comment section on the } \\
\text { assignment task (s20) }\end{array}$ & 143 & 111 & $254(98 \%)$ & 127 & 22.6 \\
\hline Navigate Moodle grading book (s21) & 107 & 150 & $\begin{array}{c}257 \\
(100 \%)\end{array}$ & 128.5 & 30.4 \\
\hline $\begin{array}{l}\text { Accomplish the quiz and assignment in } \\
\text { timely manner (s22) }\end{array}$ & 145 & 112 & $\begin{array}{c}257 \\
(100 \%)\end{array}$ & 128.5 & 23.3 \\
\hline
\end{tabular}

Moodle-mediated language testing might be classified as either linear, adaptive, or semi-adaptive. Linear tests determine the equivalent quantity of test objects in the same order as all test takers. In a linear test case, English test takers can access the previous or earlier items. Automation Moodle-based test participants choose each task systematically test (Al Nadabi. 2015). This condition referred to the classifications of adaptive. Meanwhile, semi-adaptive concentrated to the electronic testing with capabilities to select randomly developed on the course designer.

"We could observe the answer in Moodle learning, yet we did not have the facility for all the lecturers. English course had given us the chance to observe the answer. We had a variety of assessments in English learner testing. I did not like to complete all the answer because it was so many. I had complained the quantity to my lecturers."

Moodle is helpful to implement academic matters. This strategy performs it conceivable to apply the online classroom design when learners were acquainted with the English material before the English lecture begins. English test tasks most frequently affect the authentic portrayal of text-answered, and they perform for reviewing for content perception and stimulating comprehension. Kapsargina and Olentsova (2020) revealed that conventional Moodle English tests essentially concentrate on investigating the memorization of features, expressions, and signs, which is undividedly achievable externally understanding the cogitative test Moodle concept's character. The circumstances were unable to confirm that the lecturers' idea matches how the appropriate topics are given in the text-material accepted by the language learners. Therefore, it is desirable to define simplistic affirmation tests as critical in the electronic class attribute.

"Grading is important to know our achievement. I think this was my favourite feature in Moodle.

We could observe grade achievement in the English course. That became beneficial for me to know the maximum or minimum achievement in each subject."

It is essential to consider any technical details. Moodle empowers English lecturers to generate multiple testing tests. For this matter, it remains tolerably acceptable to manage numerous tests include multiple-choice tests, short answer tests, matching tests, gap tests, true/false statements. The most uncertain tests are gap texts and multiple-choice tests, where learners need to choose the blank or missing words. In Moodle cases, this kind of test is performed very thoroughly. Bilanová (2019) suggested that English lecturers or instructors were advised to establish the condition to more demand electronic testing in the Moodle system. Therefore, language learners could gain constructive feedback for each item.

"Moodle electronic testing was new for me, and I need time to adjust to the environment. The lecturers had informed me about the systematical assessment in the system. It was a little bit confusing at first time, but I can manage it now. Our class is in Moodle. We can communicate freely through the Moodle feature and share our thought about some topics."

The ability to acquire English proficiency with principal references, the theoretical material description should be analyzed and correlated to the actual problem. The central learning English sources are frequently presented at the Moodle course, but this condition might be favourably realized within the Moodle instruction course's online assistance. Besides comprehensive multiple-choice tests and integrated answers, Songbin and Fanqi (2015) recommended that it is relevant to apply gap answer and true/false test. It is essential to concentrate not on the exact text arrangement of the entire implication text although conceding the lecturers' evaluation and associating it with the language learning direction.

\section{CONCLUSION}

Page | 173 
The LMS Moodle Self-Efficacy Scale was designed to regulate language learnings' perception of their LMS Moodle capabilities as the electronic learning media. The component elaborated on the 22 categorizations in integrating LMS Moodle and language learning. Efficacy expectations may motivate language learners to enhance commitment to accomplishing their craved results. Learners with high selfesteem in their capacities are acknowledged to have a definite insight of efficacy. They did not accept challenging assignments as barriers to bypass, but preferably, they consider it a challenge to improve their experiences. They established exciting purposes for themselves, performed to them, and immediately increased their understanding of efficacy if they missed an assessment. Conversely, learners with less confidence or doubts concerning their abilities try to avoid difficult assignments because it might intimidate them, and those learners are reflected to manage below-felt efficacy. LMS Moodle selfefficacy assumption is developed on language learning three meaningful sources of knowledge: Moodle Self-Efficacy of Accessing, Moodle Self-Efficacy of Communication, and Moodle Self-efficacy of Electronic Testing and Feedback.

Self-efficacy has been an essential construct for language learning achievement in virtual learning situations, and Its meaning has been compatible through all pedagogical activities' levels, different learner cultures, and diverse learning fields. Self-efficacy propositions should be composed with consideration provided to the language achievement measure and comparable in specificity. Learners' knowledge of their achievement presents to the establishment of such a decision and influences the opportunity, integration, understanding, and function of knowledge on consequent self-efficacy perceptions. Self-efficacy is a progressive assortment of self-optimism that describes practice areas and communicates largely with other online environment pedagogical members.

\section{REFERENCES}

Al Bataineh, K. B., Banikalef, A., \& H Albashtawi, A. (2019). The effect of blended learning on EFL students' grammar performance and attitudes: An investigation of Moodle. Arab World English Journal (AWEJ) Volume, 10.

Al Nadabi, Z. (2015). Features of an online English language testing interface. Australasian Society for Computers in Learning and Tertiary Education, Perth, 30, 369-373.

Alhothli, N. I. (2015). Investigating the impact of using Moodle as an e-learning tool for students in an English language institute.

Alqurashi, E. (2016). Self-efficacy in online learning environments: A literature review. Contemporary Issues in Education Research (CIER), 9(1), 45-52.

Baltaoğlu, M. G., \& Güven, M. (2019). Relationship between self-efficacy, learning strategies, and learning styles of teacher candidates (Anadolu University example). South African Journal of Education, 39(2).

Bilanová, M. (2019, July). English Linguistics Undergraduates' Experience with Moodle in Blended Learning Environment: A Preliminary Study. In 2019 International Symposium on Educational Technology (ISET) (pp. 16-20). IEEE.

Chang, M. M., \& Lan, S. W. (2019). Exploring undergraduate EFL students' perceptions and experiences of a Moodle-based reciprocal teaching application. Open Learning: The Journal of Open, Distance and e-Learning, 1-16.

Chen, C. P. (2018). Understanding mobile English-learning gaming adopters in the self-learning market: The Uses and Gratification Expectancy Model. Computers \& Education, 126, 217-230.

Churiyah, M., Sholikhan, S., Filianti, F., \& Sakdiyyah, D. A. (2020). Indonesia education readiness conducting distance learning in Covid-19 pandemic situation. International Journal of Multicultural and Multireligious Understanding, 7(6), 491-507.

De Smul, M., Heirweg, S., Van Keer, H., Devos, G., \& Vandevelde, S. (2018). How competent do 
teachers feel instructing self-regulated learning strategies? Development and validation of the teacher self-efficacy scale to implement self-regulated learning. Teaching and Teacher Education, 71, 214-225.

Gundu, N., \& Ozcan, D. (2017). Implementation of the Moodle system into EFL classes. Profile Issues in TeachersProfessional Development, 19, 51-64.

Hasani, L. M., Adnan, H. R., Sensuse, D. I., \& Suryono, R. R. (2020, September). Factors Affecting Student's Perceived Readiness on Abrupt Distance Learning Adoption: Indonesian HigherEducation Perspectives. In 2020 3rd International Conference on Computer and Informatics Engineering (IC2IE) (pp. 286-292). IEEE.

Iwata, J., Clayton, J., \& Saravani, S. J. (2017). Learner autonomy, microcredentials and self-reflection: a review of a Moodle-based medical English review course. International Journal of Information and Communication Technology, 10(1), 42-50.

Kang, Y. N., Chang, C. H., Kao, C. C., Chen, C. Y., \& Wu, C. C. (2019). Development of a short and universal learning self-efficacy scale for clinical skills. PloS one, 14(1), e0209155.

Kapsargina, S., \& Olentsova, J. (2020, March). Experience of using LMS MOODLE in the organization of independent work of bachelors in teaching a foreign language. In International Scientific Conference" Far East Con"(ISCFEC 2020) (pp. 537-544). Atlantis Press.

Kapsargina, S., \& Olentsova, J. (2020, March). Reasonability of using LMS Moodle tests as a form of control in teaching a foreign language for students of secondary vocational education. In "New Silk Road: Business Cooperation and Prospective of Economic Development"(NSRBCPED 2019) (pp. 811-815). Atlantis Press.

Kerimbayev, N., Nurym, N., Akramova, A., \& Abdykarimova, S. (2020). Virtual educational environment: interactive communication using LMS Moodle. Education and Information Technologies, 25(3), 1965-1982.

Louhab, F. E., Bahnasse, A., \& Talea, M. (2017, October). Smart adaptive learning based on moodle platform. In Proceedings of the Mediterranean Symposium on Smart City Application (pp. 1$5)$.

Martin, F., \& Tutty, J. I. (2008, March). Learning Management System Self-efficacy of online and hybrid learners: Using LMSES scale. In Proceeding of the UNC Teaching and Learning with Technology Conference, Raleigh, NC.

Müller, N. M., \& Seufert, T. (2018). Effects of self-regulation prompts in hypermedia learning on learning performance and self-efficacy. Learning and Instruction, 58, 1-11.

Nadeak, B. (2020). The effectiveness of distance learning using social media during the pandemic period of covid-19: A case in universitas kristen Indonesia. International Journal of Advanced Science and Technology, 29(7), 1764-1772.

Nalliveettil, G. M., \& Alenazi, T. H. K. (2016). The impact of mobile phones on English language learning: Perceptions of EFL undergraduates. Journal of language teaching and research, 7(2), 264.

Natalia, K., \& Julia, O. (2018). New use of MOODLE tools for distance English language learning (experience of Krasnoyarsk State Agrarian University). International Multidisciplinary Scientific GeoConference: SGEM, 18(5.4), 225-232.

Natalia, K., \& Julia, O. (2018). New use of MOODLE tools for distance English language learning (experience of Krasnoyarsk State Agrarian University). International Multidisciplinary Scientific GeoConference: SGEM, 18(5.4), 225-232.

Nawaila, M. B., Kanbul, S., \& Alhamroni, R. (2020). Technology and english language teaching and learning: a content analysis. Journal of Learning and Teaching in Digital Age, 5(1), 16-23.

Pikhart, M. (2019). Interculturality in blended learning: challenges of electronic communication. In Smart Education and e-Learning 2019 (pp. 97-106). Springer, Singapore.

Schmid, E. C. (2017). Teacher education in computer-assisted language learning: A sociocultural and 
linguistic perspective. Bloomsbury Publishing.

Shishkina, N. M., \& Malykhina, N. I. (2015). Applying MOODLE in teaching and learning English. In ОБУЧАЯ, ВДОХНОВЛЯЙ: К НОВЫМ ВЫСОТАМ ПЕДАГОГИЧЕСКОГО MACTЕРСТВА (pp. 95-97).

Shurygin, V. Y., \& Krasnova, L. A. (2016). Electronic Learning Courses as a Means to Activate Students' Independent Work in Studying Physics. International Journal of Environmental and Science Education, 11(8), 1743-1751.

Songbin, B., \& Fanqi, M. (2015, April). The design of massive open online course platform for English translation learning based on Moodle. In 2015 Fifth International Conference on Communication Systems and Network Technologies (pp. 1365-1368). IEEE.

Sun, J. C. Y., \& Hsu, K. Y. C. (2019). A smart eye-tracking feedback scaffolding approach to improving students' learning self-efficacy and performance in a $\mathrm{C}$ programming course. Computers in Human Behavior, 95, 66-72.

Syakur, A. (2020). The Effectiveness of English Learning Media through Google Classroom in Higher Education. Britain International of Linguistics Arts and Education (BIoLAE) Journal, 2(1), 475-483.

Troussas, C., Chrysafiadi, K., \& Virvou, M. (2019). An intelligent adaptive fuzzy-based inference system for computer-assisted language learning. Expert Systems with Applications, 127, 85-96.

Tsai, M. J., Wang, C. Y., Wu, A. H., \& Hsiao, C. Y. (2021). The Development and Validation of the Robotics Learning Self-Efficacy Scale (RLSES). Journal of Educational Computing Research, 0735633121992594.

Wang, S. L., \& Batbileg, E. (2020). Effect and Scientific Verification of Innovative English Teaching and Learning through an International Networking Instructional System. Symmetry, 12(9), 1510 .

Yavuzalp, N., \& Bahcivan, E. (2020). The online learning self-efficacy scale: its adaptation into Turkish and interpretation according to various variables. Turkish Online Journal of Distance Education, 21(1), 31-44.

Yeou, M. (2016). An investigation of students' acceptance of Moodle in a blended learning setting using technology acceptance model. Journal of Educational Technology Systems, 44(3), 300-318.

Yeou, M. (2016). An investigation of students' acceptance of Moodle in a blended learning setting using technology acceptance model. Journal of Educational Technology Systems, 44(3), 300-318.

Zimmerman, W. A., \& Kulikowich, J. M. (2016). Online learning self-efficacy in students with and without online learning experience. American Journal of Distance Education, 30(3), 180-191. 